
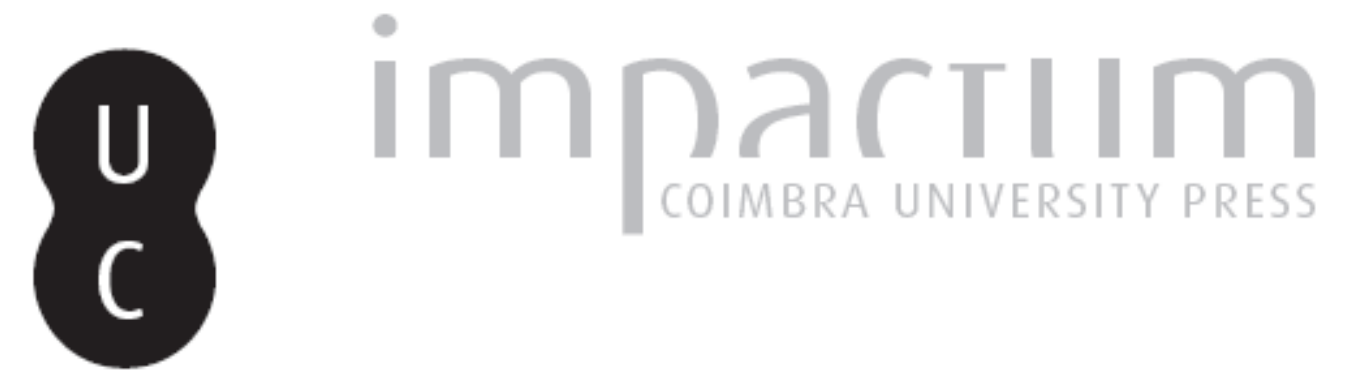

\title{
A História da América Portugueza (1730) de Sebastião da Rocha Pita: o contexto, o autor, a obra
}

\author{
Autor(es): $\quad$ Jesus, Roger Lee Pessoa de
}

Publicado por: Centro de História da Sociedade e da Cultura

URL persistente:

URI:http://hdl.handle.net/10316.2/39480

DOI:

DOI:http://dx.doi.org/10.14195/1645-2259_11_6

Accessed : $\quad$ 26-Apr-2023 15:27:33

A navegação consulta e descarregamento dos títulos inseridos nas Bibliotecas Digitais UC Digitalis, UC Pombalina e UC Impactum, pressupõem a aceitação plena e sem reservas dos Termos e Condições de Uso destas Bibliotecas Digitais, disponíveis em https://digitalis.uc.pt/pt-pt/termos.

Conforme exposto nos referidos Termos e Condições de Uso, o descarregamento de títulos de acesso restrito requer uma licença válida de autorização devendo o utilizador aceder ao(s) documento(s) a partir de um endereço de IP da instituição detentora da supramencionada licença.

Ao utilizador é apenas permitido o descarregamento para uso pessoal, pelo que o emprego do(s) título(s) descarregado(s) para outro fim, designadamente comercial, carece de autorização do respetivo autor ou editor da obra.

Na medida em que todas as obras da UC Digitalis se encontram protegidas pelo Código do Direito de Autor e Direitos Conexos e demais legislação aplicável, toda a cópia, parcial ou total, deste documento, nos casos em que é legalmente admitida, deverá conter ou fazer-se acompanhar por este aviso.

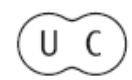




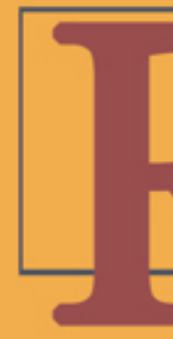

\section{evista de História} da Sociedade e da Cultura

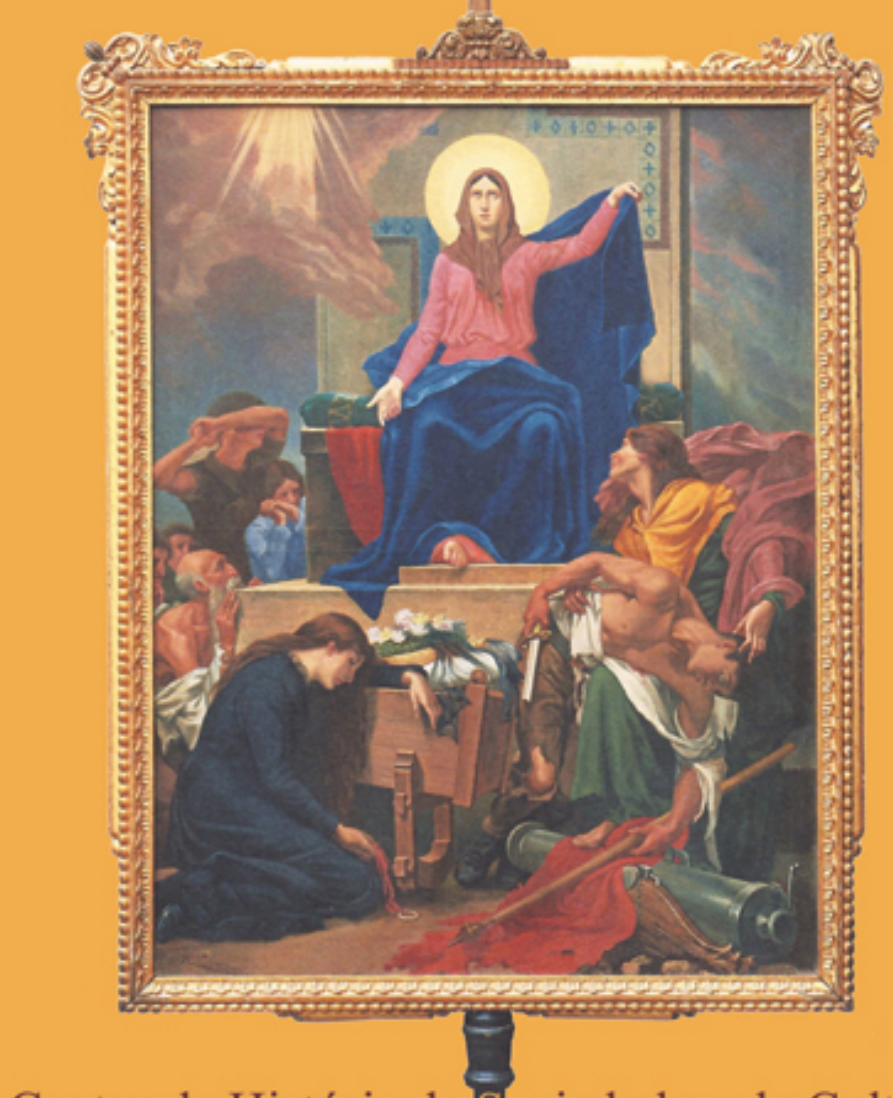

Centro de História da Sociedade e da Cultura Universidade de Coimbra 


\title{
A História da América Portugueza (1730) de Sebastião da Rocha Pita: o contexto, o autor, a obra*
}

\author{
Roger Lee Pessoa de Jesus \\ Mestrando em História Moderna - Universidade de Coimbra \\ rogerlee.pj@gmail.com \\ Texto recebido em/ Text submitted on: 25/02/2011 \\ Texto aprovado em/ Text approved on: 06/10/2011
}

\section{Resumo/Abstract:}

Criada em 1720 sob acção régia, a Academia Real da História Portuguesa procurou construir um novo modelo historiográfico. Sebastião da Rocha Pita, académico supranumerário desta instituição no Brasil, publica em 1730 a História da América Portugueza. Seguindo o ambiente académico da época e o percurso do autor, procuramos enquadrar esta História do Brasil (a primeira a ser publicada) observando, do ponto de vista historiográfico, algumas questões mais relevantes, como seja o descobrimento desse novo mundo, a União Dinástica e a Restauração, o carácter sagrado e a intervenção divina nesse território ultramarino.

Created in 1720 under royal patronage, the Royal Academy of Portuguese History aimed to build a new model for historiography. Sebastião da Rocha Pita, supernumerary academician of this institution in Brazil, published in 1730 the História da América Portuguesa (History of Portuguese America). Following the academic environment of this époque and the path of his research, we try to frame this History of Brazil (the first to be published) from a historiographical point of view, regarding some more relevant issues such as the discovery of this new world, the Dynastic Union and the Restoration, the sacred nature and divine intervention in this overseas territory.

Palavras chave/Keywords:

Historiografia; História do Brasil; Academia Real da História Portuguesa.

Historiography; History of Brazil; Royal Academy of Portuguese History.

* Este estudo resulta da investigação realizada no seminário «Pensamento e Culturas II» no âmbito do mestrado em História. Época Moderna da Faculdade de Letras da Universidade de Coimbra, orientado pela Prof. Doutora Isabel Ferreira da Mota, a quem agradecemos todo o apoio e incentivo dado na preparação deste artigo. Relembramos também a ajuda dada por D. Conceição França (do Instituto de História da Expansão Ultramarina da FLUC), Ana Rita Rocha e Ricardo Rodrigues. 
Publicada pela primeira vez em 1730, a Historia da America Portugueza desde o anno de mil e quinhentos do seu descobrimento, até o de mil e setecentos e vinte e quatro, da autoria de Sebastião da Rocha Pita, apresentou uma vitalidade considerável, sendo reimpressa duas vezes ao longo do século XIX (em 1878 no Brasil, e em 1880 em Portugal ${ }^{1}$ ), e cerca de três vezes no século $\mathrm{XX}$, marcando irreversivelmente a historiografia acerca do Brasil. O autor, membro da Academia Real da História Portuguesa, desenvolve a História do Brasil numa perspectiva setecentista, enquadrando-se nos moldes da época.

Pretendemos, ao longo deste trabalho, tirar o véu à Historia da América Portugueza, e observar de que forma Rocha Pita encarou alguns factos e temáticas relevantes da História do Brasil. Tentamos delinear, ao longo das páginas escritas por Rocha Pita, as semelhanças, as diferenças e até as novidades, apresentadas por este autor na obra que o imortalizou na historiografia portuguesa de origem brasileira.

\section{$O$ autor e a cultura académica de setecentos}

Inaugurada a 8 de Dezembro de 1720, no Paço dos Duques de Bragança, a Academia Real da História Portuguesa foi criada sob os auspícios do monarca D. João V. Pretendia escrever a história dita secular e eclesiástica do reino ${ }^{2}$, redigindo Memórias (assim conhecidos os trabalhos da Academia, por pretenderem recolher a memória existente sobre o assunto em questão - reinado, diocese, província, etc.) devendo ser escritas a partir de uma base fortemente consolidada na investigação. Assim, a crítica à fonte e aos

1 Cf. MORAES, Rubens Borba de - Bibliografia Brasileira do Período Colonial. São Paulo: Instituto de Estudos Brasileiros/USP, 1969, p. 290-291. Utilizamos a primeira edição (PITA, Sebastião da Rocha - Historia da America Portugueza desde o anno de mil e quinhentos do seu descobrimento, até o de mil e setecentos e vinte e quatro. Lisboa Occidental: $\mathrm{Na}$ officina de Joseph Antonio da Sylva, 1730), citando-a apenas como Historia da America Portugueza, e identificando o livro e o parágrafo (§) referente, de forma a facilitar a consulta em qualquer edição da obra.

2 Cf. MOTA, Isabel Ferreira da-A Academia Real da História. Os intelectuais, o poder cultural e o poder monárquico no séc. XVIII. Coimbra: Edições Minerva Coimbra, 2003, p. 62 . 
factos era imprescindível. A Academia não se firmava apenas através dos seus académicos de número (o círculo próximo às conferências periódicas) mas também através daqueles que se encontravam espalhados por todo o território português, incluindo, nos espaços ultramarinos, os académicos supranumerários, garantindo que os debates e as questões produzidas no seio desta instituição não se mantivessem apenas aí, mas extravasassem «[...] os muros da Academia» e tivessem repercussão por «todo o "reiyno e mundo literario", tornando-se públicas» ${ }^{3}$.

Através do serviço académico, os ilustres membros demonstravam as suas aptidões perante os seus pares e perante o rei. O próprio Conde de Ericeira, peça fulcral na criação desta instituição, refere-a como "tribunal académico" ". Assim, a única hierarquia tomada em conta era feita tendo por base o mérito pessoal - veja-se que até nas reuniões os académicos se sentavam sem qualquer tipo de ordem específica ou de precedência ${ }^{5}$. Aliada a esta cultura de mérito, encontramos obrigatoriamente uma «[... "cultura do serviço", entendido como obediência e capacidade adquirida, aplicação e disciplina» ${ }^{6}$, que não é apenas serviço mas também considerado "prémio" , criando assim um "círculo vicioso", oscilando entre o mérito e o serviço, ambos consequência lógica um do outro.

Tomada, então, como arquétipo da organização da elite intelectual, a Academia Real da História serve de "mãe" para a orientação de trabalhos de índole histórica. Podemos, nomeadamente, afirmar que serviu de inspiração (entre outras academias existentes nos inícios do século XVIII) à Academia Brasílica dos Esquecidos.

3 Cf. para ambas as citações MOTA, Isabel Ferreira da - A Academia Real da História...., cit., p. 67. Acerca do enquadramento da Academia Real face ao movimento ibero-americano e europeu iluminista, veja-se o artigo de MOTA, Isabel Ferreira da - A Academia Real da História Portuguesa: uma instituição no movimento iluminista ibero-americano in Ibero-América. Convergências e reptos: justiça, propriedade, instituições, liberdade e segurança. Actas do X Congresso das Academias Ibero-Americanas da História. Lisboa: Academia Portuguesa da História, 2007, vol. I, p. 101-119.

4 Collecçam dos documentos e memorias da Academia Real da Historia Portugueza. Lisboa Occidental: na officina de Pascoal da Sylva, 1 de Abril de 1728. Doravante, citaremos esta colecção apenas como Collecçam dos documentos... seguindo-se a referência à data da notícia da conferência.

5 MOTA, Isabel Ferreira da - A Academia Real da História ..., cit., p. 322.

6 Idem, ibidem, p. 327.

7 Idem, ibidem, p 332. 
Efectivamente, sob o manto do governador do Estado do Brasil, D. Vasco Fernandes César de Meneses, esta Academia foi fundada a 7 de Março de $1724^{8}$. Os académicos estavam «[...] afinados com as aspirações régias de enaltecer, pela produção intelectual, a soberania lusa nos trópicos americanos» ${ }^{9}$. A escolha do nome para a academia não foi, obviamente, inocente, sendo certo que fazia «[...] alusão ao desejo de incorporação dos eruditos americanos ao orbe literário metropolitano» ${ }^{10}$, constituindo-se como um «novo foco cultural», substituindo o «principal centro de vida literária» ${ }^{11}$ da Baía, o Colégio dos Jesuítas. Não obstante, a criação desta academia e a participação destes letrados em cerimónias públicas, que «[...] se consideravam a si próprios “esquecidos" no Brasil», leva a crer em «[...] mais uma necessidade de reprodução na periferia de modelos forjados na Europa, do que uma qualquer resistência das margens em relação ao centro» ${ }^{12}$.

Das várias tentativas encetadas com o objectivo de criar uma história total do território brasileiro ${ }^{13}$, nenhum trabalho coerente e completo emergiu. Sebastião da Rocha Pita realizou tal tarefa, alcançando a glória de publicar a primeira história do Brasil ${ }^{14}$.

8 Cf. SERRÃ̃, Joaquim Veríssimo - A Historiografia Portuguesa. Doutrina e Crítica. Vol. III - Século XVIII. Lisboa: Editorial Verbo, 1974, p. 258; KANTOR, Iris - Esquecidos e Renascidos. Historiografia Acadêmica Luso-Americana (1724-1759). São Paulo/Salvador: Editora HUCITEC - Centro de Estudos Baianos / UFBA, 2004, p. 99.

9 PESSOTI, Bruno Casseb - Ajuntar manuscritos, e convocar escritores: o discurso histórico institucional no setecentos luso-brasileiro. Salvador: Faculdade de Filosofia e Ciências Humanas da Universidade Federal da Bahia, 2009, dissertação de mestrado em História, p. 45.

${ }^{10}$ KANTOR, Iris - ob. cit., p. 95.

${ }^{11}$ Para ambas cf. CURTO, Diogo Ramada - As práticas de escrita in BETHENCOURT, Francisco e CHAUDHURI, Kirti (dir.) - História da Expansão Portuguesa, Lisboa: Temas e Debates, 1998, vol. III, p.436.

${ }^{12}$ Cf. CURTO, Diogo Ramada - ob. cit., p. 439.

${ }^{13}$ SERRÃO, Joaquim Veríssimo - ob. cit., p. 259.

${ }^{14}$ Destacou-se não apenas na escrita da história, como na poesia: veja-se a tese de PINTO, Nilton de Paiva - A Poesia de Rocha Pita na Academia Brasílica dos Esquecidos. Belo Horizonte: Faculdade de Letras da UFMG, 2007, 2 vols, tese de mestrado em Literatura Brasileira; KANTOR, Iris - ob. cit., p. 101. 
Sebastião da Rocha Pita nasceu a 3 de Maio de $1660^{15}$ na cidade de Baía, Brasil. Filho do Capitão João Velho Gondim, natural de Ponte de Lima, e de D. Beatriz da Rocha Pita, natural de Pernambuco, realizou os seus estudos no colégio da Companhia de Jesus na Baía. Alguns biógrafos colocam-no posteriormente a estudar em Coimbra, formando-o bacharel em Cânones, contudo, não existe qualquer referência, nos registos da Universidade ${ }^{16}$. Assim, tendo estado alguns anos em Portugal, ou não, desempenhou algumas funções relevantes na Baía: vereador do Senado, e Coronel de Ordenanças dos Privilegiados ${ }^{17}$. Recebeu mercê de Fidalgo da Casa Real $\left(1701^{18}\right.$ e 1703$)$ e o hábito da Ordem de Cristo (1679). Sendo homem de relevo encontramos a sua nomeação a académico supranumerário da Academia Real da História na conferência, dada pela dita Academia, a 28 de Agosto de $1721^{19}$. Na carta recebida pela Academia, agradecendo a nomeação, o dito membro esperava que «[...] no meu talento haja esfera em que possa caber tão alto emprego» ${ }^{20}$.

\section{A «Historia da America Portugueza»}

A obra de Rocha Pita destacou-se, à época, por ser a primeira história do Brasil publicada, abarcando todo o seu território. Segundo Joaquim Romero Magalhães, «a fidedignidade essencial da História da América Portugueza

${ }^{15}$ E não 1668, como afirmou Joaquim Veríssimo SERRÃO - ob. cit., p. 262. Confirme-se na obra de Innocencio Francisco da SILVA - Diccionario Bibliographico Portuguez. Lisboa: Na Imprensa Nacional, 1862, t. VII, pp.223-223; e na de Diogo Barbosa MACHADO Bibliotheca Lusitana. Coimbra: Atlântida Editora, 1966, t. III, p. 700.

${ }^{16}$ Confirmámos no Arquivo da Universidade de Coimbra a não existência de qualquer ficha alusiva ao nosso autor. Somente o tio, João da Rocha Pita, surge cursado em Coimbra.

${ }^{17}$ Cf. SERRÃO, Joaquim Veríssimo - ob. cit., p. 262; SILVA - Innocencio Francisco da - ob. cit., p. 222; e JÚNIOR, Dantas - Rocha Pita. Baía: Publicações da Universidade da Baía, 1960, p. 17-20.

18 Arquivo Nacional da Torre do Tombo (Lisboa) - Registo Geral de Mercês de D. Pedro II, liv. 4, fl. 96v.

${ }^{19}$ Cf. Collecçam dos documentos..., 28 de Agosto de 1722.

${ }^{20}$ Publicada por Pedro de AZEVEDO - O livro 2. ${ }^{\circ}$ da correspondência expedida e recebida pela Academia Real da Historia. O Archeologo Português, vol. XXVII (1929) 71. 
não deixa de satisfazer, se bem que envolta nas roupagens barrocas de um provincianismo áulico a que não poderia fugir» ${ }^{21}$.

Os diversos textos escritos ao longo dos séculos XVI, XVII e XVIII procuravam em grande parte descrever o território brasileiro (fauna, flora, índios), esquecendo a história da ocupação efectiva do território (referindo-o, em alguns casos, apenas a parte dele). É caso, por exemplo, das obras de Pero de Magalhães Gândavo ${ }^{22}$, Gabriel Soares de Sousa ${ }^{23}$, Ambrósio Fernandes Brandão ${ }^{24}$ ou ainda André João Antónil ${ }^{25}$. Destacamos a História do Brasil terminada em 1627, de Frei Vicente do Salvador ${ }^{26}$. Esta última é considerada, de facto, a primeira História do Brasil, pois abarca na totalidade o território ultramarino, não tendo sido tomada como referência por Rocha Pita, tendo em conta a data da publicação.

Para todos os efeitos, podemos assim concluir que a «Historia da America Portugueza» é a primeira História do Brasil, sobretudo graças à ampla divulgação que ganhou. Salientemos, todavia, que outro académico da Academia Real se propôs a escrever uma obra sobre a história do território brasileiro: segundo Manuel Teles da Silva, na sua Historia da Academia Real da Historia Portugueza, o P. Luis de Carvalho, jesuíta na Baía, deu conta aos censores que se a própria Academia «[...] lhe encomendasse a Historia da America, a comporia com facilidade, por ter junto já muitas memorias, e noticias para este fim $»^{27}$. O pedido não foi aceite, pois $«[\ldots]$ como toda a

${ }^{21}$ MAGALHÃES, Joaquim Romero-«As novas fronteiras do Brasil» in BETHENCOURT, Francisco e CHAUDHURI, Kirti (dir.) - História da Expansão Portuguesa..., cit., p. 27.

${ }^{22}$ GÂNDAVO, Pero de Magalhães - História da Província Santa Cruz a que vulgarmente chamamos Brasil. Lisboa: Assírio \& Alvim, 2004, publicada em 1576. Este autor refere-nos que escreveu a obra «[...] por não haver até agora pessoa que a empreendesse, havendo já setenta e tantos ano que esta província foi descoberta» p. 37, citada a partir daqui apenas como História da Província Santa Cruz.

${ }^{23}$ Veja-se a edição mais recente: SOUSA, Gabriel Soares de - Notícia do Brasil. Lisboa: Publicações Alfa, 1989, publicado pela primeira vez somente em 1823.

${ }^{24}$ BRANDÃO, Ambrósio Fernandes - Diálogos das Grandezas do Brasi., Rio de Janeiro: Dois Mundos Editora, 1943, datando o texto de 1618 sendo publicado no século XIX.

${ }^{25}$ ANTONIL, André João - Cultura e Opulência do Brasil. Lisboa: Publicações Alfa, 1989, cuja primeira edição data de 1711 .

${ }^{26}$ Veja-se a edição de 1965: SALVADOR, Frei Vicente do - História do Brasil. 1500-1627, ed. Capistrano de ABREU et al. São Paulo: Edições Melhoramentos, 1965, tendo sido publicada pela primeira vez no século XIX.

${ }^{27}$ SILVA, Manuel Teles da - Historia da Academia Real da Historia Portugueza. Lisboa Occidental: Na officina de Joseph Antonio da Sylva, 1727, p. 146. 
Historia estava já distribuída pelos Academicos, se se encomendasse a outro escritor alguma das suas partes, porque, que ou se não esperava tanto dos nomeados, ou que ociosamente se multiplicavam os empregos». Acabaram por o informar de que poderia prosseguir com a obra, no entanto sem esta ser um pedido da Academia, mas promovendo-a posteriormente, «[...] na qual depois de concluída, e approvada, poderia usar do nome de academico» ${ }^{28}$. Apesar deste incentivo à publicação (que poderia tomar a mesma forma que a obra de Rocha Pita assumiu) não conhecemos qualquer obra do referido jesuíta acerca do Brasil.

Consideramos necessário tentar reconstruir o percurso do nosso autor ao escrever esta obra. Ora, como já dissemos, a Academia Real da História informou Rocha Pita do seu convite para membro supranumerário da mesma em 1721. Na sessão de 28 de Agosto desse ano, o director «[...] deu conta de se haverem feito académicos de Província [...] na Bahia a Sebastião da Rocha Pita ${ }^{29}$ - notemos, contudo, que este apenas surgirá na lista dos académicos na Collecçam dos documentos de 1722. Informado de tal por carta, o novo académico respondeu em Agosto do ano seguinte (12 de Agosto de 1722), dando conta que já estava «[...] compondo a Historia da nossa Portugueza America e já [vou] no $4^{\circ}$ livro dos dês, em que pertendo dividir o volumen [...] desde o anno de 1500 do seu descobrimento athe o de 1722 em que estamos» ${ }^{30}$. Na sessão de 23 de Dezembro desse mesmo, dava-se notícia que o dito membro «[...] dava conta à Academia de que estava compondo a Historia da America Portugueza ${ }^{31}$. Enquadrando então a obra no projecto da Academia, esta instituição aceitou de bom grado a notícia. A própria Junta de Censores afirmava ao autor, em carta de 10 de Abril de 1723 que achava necessário «[...] segurar-lhe quanto será conveniente que Vossa Mercê conclua esta obra» ${ }^{32}$.

${ }^{28}$ Para ambas, cf. SILVA, Manuel Teles da-Historia da Academia Real..., cit., p. 146- 147.

${ }^{29}$ Colleç̧am dos documentos..., 28 de Agosto de 1721.

${ }^{30}$ AZEVEDO, Pedro de - O livro 2. ${ }^{\circ}$ da correspondência expedida e recebida pela Academia Real da Historia. O Archeologo Português, vol. XXVII (1929) 71-72.

${ }^{31}$ Collecçam dos documentos..., 23 de Dezembro de 1722.

32 AZEVEDO, Pedro de - O livro 2. ${ }^{\circ}$ da correspondência expedida e recebida pela Academia Real da Historia. O Archeologo Português. Vol. XXVI (1924) 91. 
Assim, a obra já se encontrava em desenvolvimento independentemente do facto de Rocha Pita ser membro da Academia Real da História. O autor já se apresentava "mergulhado" nesse projecto. A sua junção a esta instituição, bem como à Academia Brasílica dos Esquecidos, com certeza beneficiou a obra, mas pode não ter sido fundamental.

No ano seguinte, na notícia da sessão de 8 de Março de 1724, demos conta de de nova correspondência do nosso autor baiano, tendo em conta que se receberam «[...] cartas dos Deputados do Cabido, Senado da Camara da Cidade de Coimbra [...] e dos Academicos Sebastião da Rocha Pitta...» $\rangle^{33}$ - não informando do conteúdo da dita carta. Só voltamos a ter notícia do autor a 22 de Novembro de 1725, quando o director informou que «[...] o Academico Sebastiao da Rocha Pita remettera o livro, que se offereceo a compor, para que dando se lhe licença pudesse usar do nome de Academico supranumerário. Este livro vem muito bem escrito, e o seu titulo he Historia da America Portugueza desde o anno de 1500 do seu descobrimento, até o de $1724 »^{34}$. Supomos que a obra tenha sido remetida para o reino nesse mesmo ano de 1724, demorando a chegar pelo próprio tempo da viagem, passando por um processo administrativo de triagem até chegar finalmente à Academia.

Ora, se a obra já se encontrava nas mãos da Academia em 1725, as licenças ajudam a periodizar o processo de publicação. Assim, a primeira, de António Rodrigues da Costa, data de Agosto de 1726. Desse mesmo ano datam os pareceres de D. António Caetano de Sousa (Novembro), do Director e Censores da Academia e de Frei. Manuel Guilherme, qualificador do Santo Ofício (ambos de Dezembro). O período de "licenciamento" demora até meados de 1727. A razão do hiato que decorre entre esse ano e o de 1730, ano da publicação é, de facto, uma incógnita. Não encontrámos qualquer referência na Colecção de Documentos... que pudesse explicar tal demora.

Certo é que, em Março de 1730, a obra já se encontrava à venda (saída da «officina de Joseph Antonio da Sylva, Impressor da Academia Real»), como refere a Gazeta de Lisboa de dia 30 desse mês: «Sahio novamente à luz hum livro in folio Historia da America Portugueza, que compoz o Coronel

\footnotetext{
${ }^{33}$ Collecçam dos documentos..., 8 de Março de 1724.

${ }^{34}$ Collecçam dos documentos..., 22 de Novembro de 1725.
} 
Sebastião da Rocha Pita, Fidalgo da Caza de Sua Magestade e Academico Supernumerario da Academia Real da Historia. Vende-se na logea de João Rodrigues, mercador de livros às portas de Santa Catharina ${ }^{35}$.

Em termos estruturais, a obra encontra-se dividida em dez livros, estando estes divididos em "capítulos" pelos vários parágrafos numerados e identificados à margem (na primeira edição) por um título genérico. A obra segue, em traços gerais, o proposto pela própria Academia Real: a dedicatória ao rei; o prólogo - não especificando, todavia, as fontes ou bibliografia; uma advertência - que não contemplada na estrutura proposta pela Academia - esclarece quanto à organização dos livros; não existindo uma tábua cronológica, cada livro apresenta no seu início um índice particular das suas matérias $^{36}$. O autor acrescentou no final uma lista dos «que se achão com o governo das outras Provincias, e praças do Brasil» e outra das «Pessoas naturaes do Brasil, que exercerão dignidades, e governos Ecclesiasticos, e Seculares na Patria, e fóra dela», não sendo de esquecer a existência de um «Index das cousas notaveis».

O primeiro e o segundo livro tratam do enquadramento geográfico e histórico, isto é, da história natural (da fauna e da flora) à descrição de cada província do Brasil, do descobrimento do território ao seu povoamento inicial. Do terceiro ao décimo livro encontramos a história do Brasil, organizada cronologicamente, e seguindo quase sempre a administração dos Governadores-Gerais ou dos Vice-Reis.

Enquanto narra factos da vida política, o autor não esquece as questões religiosas, intercalando a chegada, presença e expansão de diversas ordens religiosas com o governo do clero secular. Da guerra contra os holandeses até à sua época, são narradas as lutas da Restauração, contra os gentios, contra os espanhóis no Rio da Prata, a descoberta e respectiva corrida ao ouro (apresentando uma visão consciente dos seus efeitos sociais), a resistência dos escravos no quilombo dos Palmares, entre tantas outras questões. A História do reino ou até da presença portuguesa na Índia é abordada

${ }^{35}$ Gazeta de Lisboa Occidental. Lisboa: Na Officina Pascoal da Sylva, 30 de Março de 1730. Encontramos nova referência à venda da obra na Gazeta de dia 28 de Setembro do mesmo ano.

${ }^{36}$ Sobre a estrutura proposta pela Academia, veja-se MOTA, Isabel Ferreira da-ob. cit., p. $58-59$. 
quando o académico entende que esta é necessária para se compreender a conjuntura da época, ou apenas para evocar os acontecimentos do império naquele período.

Quanto às fontes, Rocha Pita vai afirmando na sua obra a leitura de alguma documentação, sem nunca referir directamente o processo de investigação. No prólogo, refere que o livro (tomando-o como um mapa) está ainda numa forma humilde «[...] assim por falta de engenho, como por não ter visto os originaes, fazendo a mayor parte das copias por informaçoens, das quaes me não pode resultar o acerto de Appelles no retrato de Elena pelos versos de Homero» ${ }^{37}$; de seguida, na advertência, este afirma que «[...] as materias, e noticias, que nella trata, são colhidas de relações fidedignas, conferidas com os Authores, que estas materias tocarão, e com particulares informações modernas, (que elles não tiverão) feitas por pessoas, que cursarão as mayores partes dos continentes do Brasil, e as depuzerão fielmente como testemunhas de facto, com a sciencia de que o Author as inquiria para compor esta Historia, cujo essencial instituto he a verdade». No livro terceiro, $\S 35$, é feita referência explícita (acerca da morte do capitão mor Estácio de Sá) que «[...] não achámos delle outra noticia» ${ }^{38}$, levando a crer num trabalho de pesquisa na documentação da época; da mesma maneira, acerca do Governador Lourenço de Veiga, afirma-se que «da sua pessoa não alcançamos individuaes noticias» ${ }^{39}$. No que diz respeito à história da presença holandesa, o autor informa-nos que a «[...] causa mayor de faltarem muitas noticias he, porque tomando os hollandezes a cidade da Bahia, queimarão os Archivos da Secretaria da Camera, da Védoria, e outros cartórios. [...] Estes descuidos nos obrigão a ser succintos na expressão dos sucessos antigos do Brasil, pela confusa luz, que nolos dispensa» ${ }^{40}$.

O que nos afirmam algumas biografias do autor não pode ser comprovado pela leitura Historia da America Portugueza, como seja o caso: «[...] fez longas digressões pelo território brasileiro e decidiu estudar holândes, francês

\footnotetext{
${ }^{37}$ Historia da America Portuguesa, Prólogo.

${ }^{38}$ Idem, Livro Terceiro, §35.

${ }^{39}$ Idem, ibidem, $\$ 82$.

${ }^{40}$ Idem, ibidem, $\$ 104$.
} 
e italiano, de modo a poder consultar documentos escritos nesses idiomas ${ }^{41}$ ou ainda que andou a investigar «[...] pelo Rio de Janeiro, S. Vicente, Lisboa e até pelos Países Baixos, revolvendo arquivos, sacudindo-lhes o pó, para alimentar o espírito com a leitura e a interpretação de documentos $\rangle^{42}$. O que temos por certo é que Rocha Pita, pelos seus meios abastados, poderá ter constituído uma biblioteca considerável, tendo até acesso a alguma informação privilegiada pelo espólio que herdou do tio, João da Rocha Pita, chanceler da Relação da Baía ${ }^{43}$.

Por fim, último ponto desta análise geral à obra, vejamos o que de mais relevante nos dizem as licenças. Da Academia Real, António Rodrigues da Costa elogia criticando dizendo que, «ainda que me parece mais elogio ou panegyrico, que Historia» ${ }^{44}$, a obra merece ser impressa, ou seja, mesmo não seguindo precisamente a "crítica" defendida pela Academia Real, esta seria uma obra a respeitar e a considerar. D. António Caetano de Sousa, pelo contrário, afirma categoricamente que esta é a «[...] única [História do Brasil], que temos seguida e completa dos dilatados, e riquíssimos Dominios, que el Rey nosso Senhor tem nesta grande parte do Mundo» ${ }^{45}$. O Pe. Joseph Barbosa, pelo Ordinário, chega a afirmar que «[...] entendo, que justamente se lhe deve dar o titulo de novo Colon, porque com o seu trabalho, e com o seu estudo nos soube descobrir outro Mundo novo no mundo descoberto» ${ }^{46}$. Com certeza, as licenças são "reflexo" da posterior boa aceitação da obra, quer no meio académico, quer pelos leitores em geral.

\section{A História na História de Sebastião da Rocha Pita}

\section{Do Descobrimento aos primeiros contactos}

A expedição de Pedro Álvares Cabral, em 1500, com destino à Índia, ainda hoje traz largos debates. Obviamente, no centro encontra-se a questão

${ }^{41}$ ALMEIDA, Palmira Morais Rocha de - Dicionário de autores no Brasil colonial. Lisboa: Edições Colibri, 2003, p. 334.

42 JÚNIOR, Dantas - ob. cit., p. 22.

${ }^{43}$ KANTOR, Iris - ob. cit., p. 203.

${ }^{44}$ Historia da America Portugueza, licença de António Rodrigues da Costa.

${ }^{45}$ Idem, ibidem, licença de D. António Caetano de Sousa.

${ }^{46}$ Idem, ibidem, licença de D. Joseph Barbosa. 
da casualidade, ou não, da chegada ao Brasil. Rocha Pita vem, assim, reforçar a corrente que defendia o descobrimento não intencional. Nas suas palavras, uma tempestade terá desviado a frota, «[...] perdidos os rumos da navegação, e conduzidos da altíssima Providencia, mais que dos porfiados ventos, na altura do Polo Antartico, dezaseis grãos, e meyo da parte do Sul, aos vinte e quatro de Abril, avistou ignorada terra, e já mais surcada costa $»^{47}$. Gândavo refere um desvio da rota para evitar as calmarias da Guinét8, enquanto Frei Vicente do Salvador (obra, recordemos, desconhecida na altura) fala simplesmente de um desvio da rota ${ }^{49}$.

Note-se que, à época de Rocha Pita, este era um tema que já suscitava dúvidas no seio da Academia Real. Encontramos, na sessão de 12 de Maio de 1722, várias dúvidas colocadas por Manuel Dias de Lima, e no meio de um extenso leque de perguntas, é colocada a seguinte questão: «Se foy a America conhecida, ou suspeitada de alguma nação antes do nosso descobrimento?» ${ }^{50}$. A existência desta incerteza demonstra que era um assunto talvez comprometedor, e consideravelmente necessário para se conseguir estabelecer uma história crítica, como aquela que a Academia pretendia.

Conjecturar uma missão secreta encomendada a Cabral, por D. Manuel, com o objectivo de tomar posse de terra já conhecida, pode ser considerado mera especulação, tendo em conta a pouquíssima base documental. Podemos, contudo, acreditar na acção pessoal do capitão ao avistar sinais de terra ${ }^{51}$.

Quanto ao nome "Brasill", como sabemos este não foi o primeiro nome dado àquele território em 1500. Pero Vaz de Caminha refere-se, no final

${ }^{47}$ Idem, ibidem, Livro Primeiro, §5.

${ }^{48}$ História da Província Santa Cruz, p. 41.

${ }^{49}$ SALVADOR, Frei Vicente do - ob. cit., p. 56.

${ }^{50}$ Collecçam dos documentos..., 12 de Maio de 1722. Não encontrámos qualquer registo de respostas dadas às dúvidas levantadas por este académico.

${ }^{51}$ Vejam-se os diferentes pontos de vista: JOHNSON, Harold e SILVA, Maria Beatriz Nizza da (coord.) - O Império Luso-Brasileiro 1500-1600, Nova História da Expansão Portuguesa, vol. VI, dir. Joel SERRÃO e A. H. de Oliveira MARQUES. Lisboa: Editorial Estampa, 1992, pp. 62-74; GUEDES, Max Justo - O descobrimento do Brasil. Oceanos 39 (Julho/Setembro 1999) 8-16; COUTO, Jorge - A expedição cabralina: casualidade versus intencionalidade. Oceanos. 39 (Julho/Setembro 1999) 18-31. 
da sua conhecida carta, «[...] da vosa ilha de Vera Cruz» ${ }^{52}$. Gândavo e Salvador remetem o nome "Brasil" para a existência e comercialização do pau-brasil ${ }^{53}$. Rocha Pita mantém esta explicação «[...] pelo pao vermelho, ou cor de brazas, que produz $\rangle^{54}$. Se ainda hoje alguns continuam a defender esta tese, parece-nos mais provável o nome ter ficado pelo peso da mítica "ilha Brasil". Como sabemos, a época medieval encheu o Atlântico de lendas e mitos acerca de ilhas afortunadas. Com a descoberta de Cabral, o território terá passado a ser referido com o nome da ilha que tanto se procurava, e posteriormente definitivamente como $\operatorname{tal}^{55}$.

Das primeiras décadas de relacionamento entre os portugueses e os índios, destacamos a história/mito do Caramuru. Segundo os escritos, Diogo Álvares Correia (nascido em Viana do Castelo) ter-se-ia fixado na Baía por volta de 1510, ficando com alcunha de Caramuru, palavra de origem tupi significando moreia ${ }^{56}$. Casado com a filha de um chefe índio, assumindo esta posteriormente o nome de Catarina Álvares, a acção deste português tem um papel predominante na construção do «[...] mito fundador da nacionalidade e $[d e]$ um arquétipo originário das relações culturais entre Brasil e Portugal $\rangle^{57}$. O próprio desenvolvimento da relação entre o português e a índia «[...] parece configurar um mito geopolítico de soberania concebido pelo colonato» ${ }^{58}$.

O que Rocha Pita nos conta entronca nesta mística do mito fundador. $\mathrm{O}$ autor procura dar a conhecer a história «[...] pelo que consta de antigos verdadeiros manuscritos, que se conservão em varias partes desta Provincia, em muitas circunstancias differente da forma, em que a escrevem os Authores, que nella fallarão» ${ }^{59}$. A actividade do português nas

${ }^{52}$ MAGALHÃES, Joaquim Romero de e MIRANDA, Susana Münch (ed.) - Os primeiros 14 documentos relativos à armada de Pedro Álvares Cabral. Lisboa: CNCDP, 1999, p. 121.

${ }^{53}$ História da Província Santa Cruz, p. 43; SALVADOR, Frei Vicente do - ob. cit., p. 58.

${ }^{54}$ Historia da America Portugueza, Livro Primeiro, §6.

${ }^{55}$ Veja-se SILVA, José Manuel Azevedo e - O Brasil Colonial. Coimbra: Faculdade de Letras da Universidade de Coimbra, 2005, p. 22-26.

${ }^{56}$ MONTEIRO, John M. - Caramuru in SILVA, Maria Beatriz Nizza da (coord.) Dicionário da História da Colonização Portuguesa no Brasil. Lisboa: Editorial Verbo, 1994.

${ }^{57}$ KANTOR, Iris - ob. cit., p. 221.

${ }^{58}$ Idem, ibidem.

${ }^{59}$ Historia da America Portugueza, Livro Primeiro, §94. 
guerras tribais, utilizando a espingarda, valeu-lhe (como já mencionámos) «[...] o nome de Caramuru-assu, que no seu idioma he o mesmo que Dragão, que sahe do mar» ${ }^{60}$. Claro, a história vai ganhando força aquando de um suposto temporal que terá levado o casal a um navio francês, que por sua vez os terá reencaminhado para França. A juntar, encontramos aí o rei francês, «[...] Henrique de Valois, segundo do nome, e Catharina de Medices, Reys Christianissimos, que informados do successo, e qualidade dos hospedes, os receberão com real agrado, e despeza» ${ }^{61}$.

Se Gândavo não faz referência a esta personagem, já Frei Vicente do Salvador abre caminho para a versão de Rocha Pita, seguindo aproximadamente o que, um século depois, o académico viria a escrever ${ }^{62}$. Apesar das incertezas, é facto que Diogo Álvares Caramuru existiu, e que o seu papel no estabelecimento dos portugueses no meio índio terá sido relevante. A História da America Portugueza vem apenas confirmar e criar novos pilares para este tão conhecido mito primordial da presença portuguesa no Brasil.

\section{Da “Dominação" Filipina à Restauração}

Como seria de esperar, os sessenta anos de União Dinástica não ficaram esquecidos na História do Brasil. Mais do que observar o que aconteceu nesse território, interessa-nos observar de que forma Rocha Pita enquanto membro da Academia Real da História nos inícios do século XVIII, registou esse período da história portuguesa ${ }^{63}$.

A perspectiva da Academia Real no século XVIII demonstra uma certa ambiguidade. Se, por um lado, esta procurava a verdade através da crítica,

${ }^{60}$ Idem, ibidem, § 97.

${ }^{61}$ Idem, ibidem, $\$ 99$.

${ }^{62}$ Cf. SALVADOR, Frei Vicente do - ob. cit., pp. 160-161.

${ }^{63}$ Sobre a perspectiva da Academia em si, veja-se algumas referências no artigo de SILVA, Taise Tatiana Quadros da - Poder e episteme na erudição histórica do Portugal setecentista: uma abordagem do programa historiográfico da Academia Real da História Portuguesa (1720-1721). História da Historiografia. 3 (Setembro 2009), (http://www.ichs.ufop.br/rhh/ index.php/revista/article/view/60, consultado a 2011.02.20). Acerca do período que medeia entre 1580-1640, cf. Vitorino Magalhães Godinho - 1580 e 1640 - Da União Dinástica à Restauração in Ensaios e Estudos. Uma maneira de pensar. Lisboa: Sá da Costa Editora, 2009, p. 421-468. 
por outro pretendeu criar uma série de dogmas, que caso fossem discutidos agitariam a perspectiva presente acerca desses sessenta anos: a veracidade das Cortes de Lamego e o juramento de D. Afonso Henriques em Ourique (que abordaremos adiante) ${ }^{64}$. Na conferência de 19 de Janeiro de 1721, o Pe. D. Manuel de Tojal da Silva informou que estava a criar uma «tábua chronologica dos reys de Portugal» e perguntava «[...] se os tres reys de Castella, que reinàrão em Portugal, havião entrar na serie dos nossos, ou como devia falar nelles» ${ }^{65}$ - prova indubitável que o assunto ainda levantava incertezas; «[...] mandando-se votar esta materia, pareceo differir a resolução para outro tempo» ${ }^{66}$. Remetia-se a dúvida para outra altura, facilitando assim a delicada situação de aceitar ou não a legitimidade da governação dos Filipes.

Rocha Pita segue a corrente, e na sua obra informa-nos que, pela eleição de Filipe II pela junta deixada pelo Cardeal-Rei, e sobretudo pelas armas («[...]que he o direito mais seguro dos Principes ${ }^{67}$ ), Portugal uniu-se à Monarquia Hispânica, porque no fundo «[...] estavão decretados aos Lusitanos sessenta annos de cativeiro naquelle Reyno (como no de Babylonia aos Hebreos, por differentes peccados de huma, e outra Nação)» ${ }^{68}$. A própria culpa do declínio do Império é da responsabilidade dessa dinastia, tendo em conta que «[...] foy maxima de Estado, ou dogma politico attenuarem o Reyno, por temerem que os Portuguezes o restituíssem à Serenissima Casa de Bragança com a mesma força, com que the fora usurpado» ${ }^{69}$.

$\mathrm{O}$ ataque holandês ao Brasil ocupa dezenas de páginas da obra do académico de origem brasileira. O livro quatro é inteiramente dedicado à presença holandesa, no ataque à Baía e na conquista de Pernambuco, bem como o livro cinco e seis (que cobrem o período da Guerra da Restauração), referindo diversas vezes a luta pela expulsão dos invasores do

${ }^{64}$ Cf. MOTA, Isabel Ferreira da - História da Academia Real ..., cit., p. 72. Não esquecemos, claro, a questão da primazia de Braga, assunto "proibido", mas que não nos interessa directamente nesta temática.

${ }_{65}^{6}$ Para ambas, cf. Collecçam dos documentos..., 19 de Janeiro de 1721.

${ }^{66}$ Idem, ibidem.

${ }^{67}$ Historia da America Portugueza, Livro Terceiro, $\$ 75$.

${ }^{68}$ Idem, ibidem.

${ }^{69}$ Idem, ibidem, $§ 77$. 
Nordeste do Brasil e as negociações diplomáticas entre Portugal e as Províncias Unidas.

Saltemos, no entanto, alguma análise mais factual desses acontecimentos, e cheguemos a 1640, ano da "gloriosa" Restauração da independência portuguesa. Retomemos agora a questão do juramento de D. Afonso Henriques, levado ao expoente no dito "Mito de Ourique"70. Como sabemos, a batalha sofreu um processo de criação "mitológica", tendo a mais antiga referência da aparição de Cristo a data de $1416^{71}$. Ganhando grande vida no século XVI, é durante o período restauracionista que o Mito de Ourique passa a dogma fundamental da existência de Portugal. Para Rocha Pita, 1640 simbolizava o fim das «[...] desgraças de Portugal, e principiavão as suas felicidades $»^{72}$, e mais, era o «[...] tempo da segunda clausula da promessa de Deos nosso Senhor, feita a El Rey D. Affonso Henriques, de que a primeira fora a vitoria, que nos deu no Campo de Ourique» ${ }^{73}$, em que Portugal havia de «[...] ser o único, permanente, e Mayor Imperio de todos os quatro tão opulentes, e inconstantes, que teve o mundo» ${ }^{74}$. Seguindo a tradição, já bem fixada no século XVIII, o autor narra-nos a promessa realizada entre Afonso Henriques e Cristo, sustentando-se em outros casos similares, sendo o principal o de Constantino e do seu famoso In hoc signo vinces. Tão milagrosa tinha sido também a Restauração em si, «[...] pela debilidade de forças, em que se achava o Reyno exhausto de gente, armas, e cabedaes, com vexações da Nobreza, introduções de tributos, tyrannias de Ministros, derrogações de privilegios, faltas de juramentos, e huma geral attenuação de todos os meyos de defensa, para proclamar liberdade» ${ }^{75}$.

Curioso é também vermos Rocha Pita colocar D. João IV no lugar de D. Sebastião: «Este era o verdadeiro Sebastião, por quem tanto suspiravão os Portugueses na antonomazia de Sebastianistas, disfarçando com a vinda

${ }^{70}$ Veja-se o estudo de síntese de BUESCU, Ana Isabel - A memória das origens. Ourique e a fundação do reino (séculos XV-XVIII) in Memória e Poder. Ensaios de História Cultural (Séculos XV-XVIII). Lisboa: Edições Cosmos, 2000, p. 11-28.

${ }^{71}$ BUESCO, Ana Isabel - ob. cit., p. 16.

${ }^{72}$ Historia da America Portugueza, Livro Quinto, §1.

${ }^{73}$ Idem, ibidem.

${ }^{74}$ Idem, ibidem.

${ }^{75}$ Idem, ibidem, $\$ 9$. 
de hum Rey desapparecido, a ancia de outro Rey desejado» ${ }^{76}$. Assim, a teoria de um rei em dois corpos ganha completa consistência nas palavras do autor, como também o afirmara anteriormente o Padre António Vieira ${ }^{77}$. O Desejado, o Encoberto, era, de facto, D. João IV, que "saíra" da nobreza para liderar uma Nação independente, nascido rei mas «[...] vassalo por tyrannia $\rangle^{78}$, ganhando a coroa que $«[\ldots]$ estava violentada em outra cabeça, e separando o Reyno daquelle corpo, que intentou reduzillo a hum pequeno membro, fazendo-o Provincia» ${ }^{79}$.

Deste período, vejamos a descrição que Rocha Pita nos dá dos dois sucessores de D. João IV. Sabemos que o curto reinado de D. Afonso VI trouxe uma certa instabilidade política, pela doença de que padecia o monarca, pelo pouco interesse que demonstrou pela governação e claro, pela proximidade do seu valido, o conde de Castelo Melhor. Segundo o autor, D. Afonso VI «tomou» os destinos da Coroa «[...] com mayores desejos de a possuir, que disposições para a governar, porque as suas distrações, impróprias da Magestade, o trazião tão apartado dos cuidados, de que necessitava a administração do Reyno, como dos remédios, de que carecião as suas continuas enfermidades, entregando-se todo só aos seus juvenis divertimentos ${ }^{80}$. Adianta-se mais ao referir a contestação dos tribunais e da nobreza à acção do seu valido visto que as resoluções «[...] não erão filhas naturaes, senão adoptivas, do seu Monarcha» ${ }^{81}$. Nas palavras de Pedro Cardim, este reinado não seguiu «[...] nenhum caminho previamente definido ou claramente estruturado, nem sequer um qualquer projecto de centralização de poder ou de construção do Estado», prevalecendo uma «[...] gestão improvisada dos desafios governativos, e a redução da actividade governativa ao provimento de ofícios e à remuneração e recompensa

${ }^{76}$ Idem, ibidem, $\$ 12$.

${ }^{77}$ Veja-se o estudo de CENTENO, Yvette - O Padre António Vieira e o segundo corpo do rei in BETHENCOURT, Francisco e CURTO, Diogo Ramada (org.) - A Memória da Nação. Lisboa: Livraria Sá da Costa Editora, 1991, p. 295-318.

${ }^{78}$ Historia da America Portugueza, Livro Quinto, $\$ 127$.

${ }^{79}$ Idem, ibidem.

${ }^{80}$ Idem, Livro Sexto, $\$ 13$.

${ }^{81}$ Idem, ibidem, §14. 
dos serviços prestados à coroa» ${ }^{82}$. Quanto ao irmão Pedro, não esqueçamos que D. João V, monarca a quem a Historia da America Portugueza ia dedicada, era descendente dessa linhagem, e que tinha sido o próprio D. Pedro II a conceder mercê de fidalgo a Sebastião da Rocha Pita. Assim, o autor declarava que «[...] no seo singular animo, e talento concorrião todas as virtudes Reaes, que se requerião para o Governo dos Impérios» ${ }^{83}$. A subir ao trono enquanto «Principe Governador», «erão no Senhor D. Pedro as virtudes mais, que os annos, e mais maduro, que a idade, o talento, cultivado em todos os exercícios Reaes na sua singular educação» ${ }^{84}$. Após uma conturbada época de guerra, e de crise política, afirmava-se um período de «[...] estabilidade política interna e externa» e que coincide com «[...] o retorno a um modelo bem definido de tomada das decisões políticas na administração central» ${ }^{85}$.

\section{A terra "santa"}

Sendo terra nova e por descobrir, o Brasil rapidamente entrou na "mira" da Igreja. A própria Coroa tinha interesse na missionação, não apenas para o reconhecimento do espaço como no aumento da própria fé cristã. Rocha Pita indica-nos que D. João III «[...] empenhou o seu Catholico zelo na empreza, assim das terras, como das almas do Brasill ${ }^{86}$, e quanto à introdução da Companhia de Jesus, em 1549 (entrando na visão estratégica que este rei tinha perante o Império ${ }^{87}$ ), o autor chega a afirmar, sugestivamente que, «[...] ao tempo em que os soldados conquistavão terras, ganhavão estes novos guerreiros almas» ${ }^{88}$.

${ }^{82}$ CARDIM, Pedro - D. Afonso VI (1656-1668). A «privança» do conde de Castelo Melhor in MATTOSO, José (dir.) - História de Portugal, vol IV - O Antigo Regime (coord. António Manuel HESPANHA). Lisboa: Editorial Estampa, 1998, p. 410.

${ }^{83}$ Historia da America Portugueza, Livro Sexto, §35.

${ }^{84}$ Idem, ibidem, $\$ 37$.

${ }^{85}$ MONTEIRO, Nuno Gonçalo - D. Pedro II regente e rei (1668-1706). A consolidação da dinastia de Bragança in MATTOSO, José (dir.) - História de Portugal, vol IV - O Antigo Regime (coord. António Manuel HESPANHA). Lisboa: Editorial Estampa, 1998, p. 411.

${ }^{86}$ Historia da America Portugueza, Livro Primeiro, $\$ 93$.

${ }^{87}$ Veja-se o estudo de SANTOS, João Marinho dos - Le Catéchisation Jésuitique dans la stratégie Impériale de Jean III in Estudos Sobre os Descobrimentos Portugueses e a Expansão Portuguesa - Vol. II. Viseu: Palimage, 2010, p. 201-208.

${ }^{88}$ Historia da America Portugueza, Livro Terceiro, §5. 
Efectivamente, a imagem do Brasil enquanto paraíso perdido ainda perdurava no século XVIII. A visão de uma região perfeita, livre de pecados, onde o Homem se poderia instalar e desenvolver-se em paz, surge pela primeira vez na carta de Pero Vaz de Caminha ${ }^{89}$.

Sendo Rocha Pita brasileiro de nascimento (da Baía), encontramos claramente um tributo à sua terra natal nas páginas da Historia da America Portugueza - ele próprio o afirma no prólogo: «[...] se entenderes, que o compuz em applausos e reverencia do Clima em que nasci, podes crer, que são seguras, e fieis as noticias que escrevo, porque os obséquios não fizerão divorcio com as verdades $\rangle^{90}$. E na senda do paraíso caracteriza o Brasil: «em nenhuma outra região se mostra o Ceu mais sereno, nem madruga mais bella a Aurora: o Sol em nenhum outro Hemisferio tem os rayos tão dourados, nem os reflexos nocturnos tão brilhantes: as Estrellas são as mais benignas, e se mostrão sempre alegres: os horisontes, ou nasça o Sol, ou se sepulte, estão sempre claros: as aguas, ou se tomem nas fontes pelos campos, ou dentro das Povoações nos aqueductos, são as mais puras $\rangle^{91}$. Encontramos explicitamente a referência quando assegura que «é enfim o Brasil Terreal Paraiso descoberto» ${ }^{92}$.

Num novo continente prestes a ser evangelizado, estranho seria não existirem vestígios de que o Deus Criador tivesse estado presente na formação de tais terras. E assim teria estado, enviando o apóstolo S. Tomé não apenas para a Índia, mas para o próprio Brasil. Ter-se-iam conservado algumas marcas físicas da sua passagem quer na América Portuguesa quer na Espanhola - unindo-as sob o mesmo patriarca e sob a mesma $\mathrm{fe}^{93}$. Claro, considerado um dos "mitos de origem" a nível religioso, de Frei Vicente do Salvador ${ }^{94}$ a Rocha Pita encontramos referências à passagem do

${ }^{89}$ Gândavo utiliza largamente tal imagem: História da Província Santa Cruz, p. 46-47.

${ }^{90}$ Historia da America Portugueza, Prólogo.

${ }^{91}$ Idem, Livro Primeiro, §2.

${ }^{92}$ Idem, ibidem. Não escapa também o elogio da sua própria terra, a Baía: Idem, Livro Segundo, §5

${ }^{93}$ Cf. KANTOR, Iris - ob. cit., p. 232-236; para o caso espanhol, veja-se CAÑIZARES-ESGUERRA, Jorge - How to write the history of the New World. Histories, epistemologies, and identities in the Eighteenth-Century Atlantic World, Stanford: Stanford University Press, 2001 .

94 «Também é tradição antiga entre eles [os índios] que veio o bem-aventurado apóstolo São Tomé a esta Bahia, e lhes deu a planta da mandioca e das bananas de São Tomé, de 
santo pelo Brasil. Este último indica-nos que «a vinda do glorioso Apostolo S. Thomé, annunciando a doutrina Catholica, não só no Brasil, mas em toda a America, tem mais razões para se crer, que para se duvidar» ${ }^{95}$, e que como prova existiam «[...] os sinaes do seu baculo, e dos seus pés, e a tradição antiga, e constante em todos estes Gentios, de que erão de hum homem de largas barbas, a quem com pouca corrupção chamavão no seu idioma Sumê, accrescentando, lhes viera a ensinar cousas da outra vida, e que não sendo delles ouvido, o fizerão ausentar ${ }^{96}$. Este discurso comprova que apesar do «[...] discurso historiográfico no mundo das academias europeias» tender «à dessacralização», o caso brasílico demonstra que «[...] houve notável concessão aos temas de natureza religiosa $\iota^{97}$.

No entanto, não apenas a presença divina se manifestou na presença de um apóstolo, mas também pela própria intervenção directa de Deus. Exemplifiquemos: a conquista de Pernambuco pelos holandeses ter-se-á dado pelo facto dos seus habitantes viverem na «[...] mayor opulência, com ventagens em grandeza a todos os outros moradores do Brasil, mas tão esquecidos da modestia, que não seguião outras leys, que as da vontade, com escandalo da Justiça, commettendo muitos delictos, em que, por se ostentarem mais famosos no poder, parecião menos observantes na Religião ${ }^{98}$. A reconquista portuguesa daquela terra mostrar-se-ia também como acto divino, pela Restauração de 1640 (não esqueçamos a questão do mito de Ourique) e contra os protestantes holandeses.

Também em 1722 se fizeram sentir sinais divinos - fortes trovoadas, cheias, inundações, afirmando Rocha Pita que «grande consternação fizerão estes sinaes do Ceo nos ânimos dos moradores da Bahia, entendendo serem

que temos tratado no primeiro livro; e eles, em paga deste benefício e de lhes ensinar que adorassem e servissem a Deus e não ao demónio, que não tivessem mais de uma mulher nem comessem carne humana, o quiseram matar e comer, seguindo-o com efeito até uma praia donde o santo se passou de uma passada à ilha de Maré, distância de meia légua, e daí não sabem por onde»-SALVADOR, Frei Vicente do - ob. cit., p. 125.

${ }^{95}$ Historia da America Portugueza, Livro Primeiro, $\$ 102$.

${ }^{96}$ Idem, ibidem, $\$ 104$.

${ }^{97}$ Para ambas, veja-se KANTOR, Iris - Do dilúvio universal ao Pai Tomé. Fundamentos teológico-políticos e mensuração do tempo na historiografia brasílica (1724-1759). Cultura. Revista de História e Teoria das Ideias. 24 (2007) 185.

${ }^{98}$ Historia da America Portugueza, Livro Quarto, §62. 
vozes, que lhes clamavão a emenda dos peccados $\rangle^{99}$. Este seria, de facto, o meio do Criador avisar os seus filhos, já que «[...] com brados semelhantes aos que experimentou nesta occasião a Bahia, costuma Deos bater às portas dos corações humanos, para gloria sua, e bem das suas creaturas, regulando-nos os castigos pela sua misericórdia» ${ }^{100}$. Não obstante, o autor demonstra estar atento aos próprios interesses dos religiosos: veja-se que perante estes sinais «[...] os Missionarios, e Parocos sabendo aproveitar a oportunidade da occasião, fizerão repetidas missoens, continuas praticas, e devotas Procissoens por toda a Cidade, e seus arrabaldes, com numerosa copia de penitentes ${ }^{101}$.

No caso das trovoadas, encontramos novamente a "mão" de Deus: em Março de 1721, «[...] começarão a fuzilar relâmpagos, e a soar trovoões, em forma, que principiando moderados, forão crescendo a tal estrondo, qual nunca fizerão na Bahia, lançando rayos, a que a misericórdia de Deus tirou as forças para não causarem ruínas, pelo que se conheceo, que vinhão mais a trazer avisos, que a fazer estragos $\rangle^{102}$.

Ao lado sagrado associava-se (quase obrigatoriamente) o lado profano. Encontramos estas "manifestações" nas descrições de fenómenos naturais, como cometas e eclipses. Vejamos alguns exemplos. O ano de 1666 (número deveras simbólico) registou a passagem de um cometa, «[...] huma das mayores calamidades, que padecera $[$ o Brasil $]$ desde o seu descobrimento» ${ }^{103}$, anunciando os estragos que viriam; o autor junta então à explicação científica a crença "popular" da época: «[...] porque ainda que os Metheoros se formão de incêndios casuaes, em que ardem os átomos, que sobindo da terra, chegão condensados à esfera, as cinzas em que se dissolvem, são poderosas assim a inficionar os ares para infundirem achaques, como a descompor os animais para obrarem fatalidades» ${ }^{104}$. Quanto ao eclipse de 1685, novamente Rocha Pita envereda inicialmente pela explicação

${ }^{99}$ Idem, Livro Décimo e Último, \$64.

${ }^{100}$ Idem, ibidem, $\$ 65$.

${ }^{101}$ Idem, ibidem, \$64.

${ }^{102}$ Idem, Livro Décimo e Último, $\$ 58$.

${ }^{103}$ Idem, Livro Sexto, $\$ 20$.

${ }^{104}$ Idem, ibidem; seguir-se-ia ao cometa uma estrondosa subida do nível médio das águas do mar, enchendo as praias de peixe, e uma prolongada época de epidemias (cf. $\$ 21$ e 22 do mesmo livro). 
científica, deixando depois o "oculto" prevalecer: «he certo que os Eclipses são naturaes, formando-os a terra que se entrepoem ao curso destes dous Planetas mayores; porém de taes accidentes póde receber sordicie, ou qualidade contagiosa o ar por razoens manifestas, ou causas occultas, e da sua corrupção resultarem doenças, senão em todo o Mundo, em algumas partes delle, como se tem experimentado em contagio, e desgraças, de que ha muitos exemplos antigios, e modernos vivos nas tradições, e nos escritos, e ainda frescos nas memorias» ${ }^{105}$ Por outras palavras, este eclipse terá trazido a epidemia da "bicha" que terá devastado todo o território brasileiro ${ }^{106}$.

Não de menos importância é, no final da obra, a "Protestação" do autor. Rocha Pita demonstra nestas breves linhas a sua visão crítica acerca das questões religiosas levantadas ao longo da obra: «Protesta o author desta Historia, que as materias, que tocarem a aparições, ou parecerem milagres, e sucessos sobrenaturaes trazidos nella, não procura tenhão mais credito, que o que se deve dar a huma Historia puramente humana, e que toda esta obra sogeita à censura da Santa Igreja Catholica Romana...» ${ }^{107}$. Todavia não nos enganemos, a fé destes homens era, de facto, intensa e (cremos) verdadeira, bem presente quando o autor se manifesta na morte prematura do príncipe D. Teodósio, filho de D. João IV, acreditando que «o Ceo the tinha decretado melhor Imperio, e não permittio [que] o lograsse mais annos a terra $\rangle^{108}$.

Deus era, para estes Homens, omnipresente: vigiando, guiando, reprimindo e observando o caminho que o Brasil, terra "santa" pela sua pureza original, ia seguindo.

\section{Em jeito de conclusão}

A Academia Real da História vem, nos inícios do século XVIII, como já referimos, incluir o conceito de "mérito" na República das Letras. No

\footnotetext{
${ }^{105}$ Idem, Livro Setimo, $\$ 32$.

${ }^{106} \mathrm{Cf}$. Idem, ibidem, $\$ 33$ a 36.

${ }^{107} \mathrm{Idem}$, protestação.

${ }^{108}$ Idem, Livro Quinto, §114.
} 
seu centro, claro, o rei, responsável pela atribuição de honras e mercês ${ }^{109}$. Rocha Pita segue o modelo, e «[...] faz "serviço" ao rei que além do serviço é também prémio» ${ }^{110}$, afirmando na sua obra que «não he justo, que mereça conseguir os prémios, quem nos requerimentos pede mais do que se lhe deve conceder» ${ }^{111}$, e que «[...] na grandeza dos Monarchas huns serviços são habilitações para outros $\rangle^{112}$. Na dedicatória, o autor interliga a própria função do rei com a do patrocínio régio à Academia («[...] porque ao Principe que lhe rege o Império pertence patrocinar-lhe a Historia ${ }^{113}$ ), e submetendo-se à sua vontade, pede que o acolha sob a sua alçada («[...] permitta-me Vossa Magestade, que dos resplendores dessa propria Esféra Regia tire uma luz para illuminar as sombras dos meus escriptos» ${ }^{114}$ ).

Não obstante a atenção dada à cultura de mérito e do serviço, o autor também estava atento ao próprio Império, e às políticas régias. Afirma assim, quanto à guerra, que «[...] aos eccos dos canhoens, e ao estrondo das caixas, se descompõem, se arruinão, se atrazão, e affugentão, por ser a guerra hum monstro tragador do genero humano, estrago das creaturas racionaes, e insensíveis (e ainda entre Catholicos) torrente, e innundação de delictos, e sacrilégios [...]. E posto que em todas as Regiones do Mundo possa a guerra fazer famosos os seus capitães, não faz os seus Principes mais amados $\rangle^{115}$. Acerca da presença efectiva portuguesa no território, Rocha Pita critica mordazmente, no prólogo da obra, que é «[...] costume sempre notado nos Portuguezes de conquistarem Imperios, e não os encarecerem ${ }^{116}$.

${ }^{109}$ MOTA, Isabel Ferreira da - ob. cit., p. 321.

${ }^{110}$ Idem, ibidem, p. 332.

${ }^{111}$ Historia da America Portugueza, Livro Terceiro, $\$ 91$.

${ }^{112}$ Idem, Livro Quarto, §107.

${ }^{113}$ Idem, Dedicatória.

${ }^{114}$ Idem, Dedicatória; Rocha Pita continua o elogio: «Foi Vossa Magestade o verdadeiro Athlante, e a fortíssima columa, que sustentando-o com as forças, e com as disposições, lhes evitou os estragos».

${ }^{115}$ Historia da America Portugueza, Livro Sexto, $\$ 40$ e 41 . Veja-se também o seu discurso na conferência proferida na Academia Brasílica dos Esquecidos, a 7 de Maio de 1724, publicado por CASTELO, José Aderaldo - O movimento academista no Brasil: 1641 -1820/22, São Paulo: Conselho Estadual de Cultura, 1969, vol. I, t. I, p. 131-140.

${ }^{116}$ Idem, Prologo. 
Temos, neste autor, um exemplo concreto de homem da República das Letras, académico, culto, e reflexo da sociedade letrada periférica do Brasil. A sua participação na Academia Brasílica dos Esquecidos atesta o interesse destas elites na actualização dos conhecimentos, na partilha dos saberes, na sociabilidade ao mais alto nível, ao jeito do resto da Europa. A escrita de uma obra como a Historia da America Portugueza realizou a procura da época por uma obra de relevo sobre o Brasil, território fundamental no contexto do Império.

Do que tentou o autor na sua obra, e do que tentámos aqui, realçamos, por fim, as suas palavras na dedicatória ao monarca, advertindo que «[...] verá Vossa Magestade em grosseiro risco delineada a parte do Novo Mundo, que entre tantas do Orbe antigo, que comprehende o circulo da sua Corôa, é a maior da sua Monarchia» ${ }^{117}$.

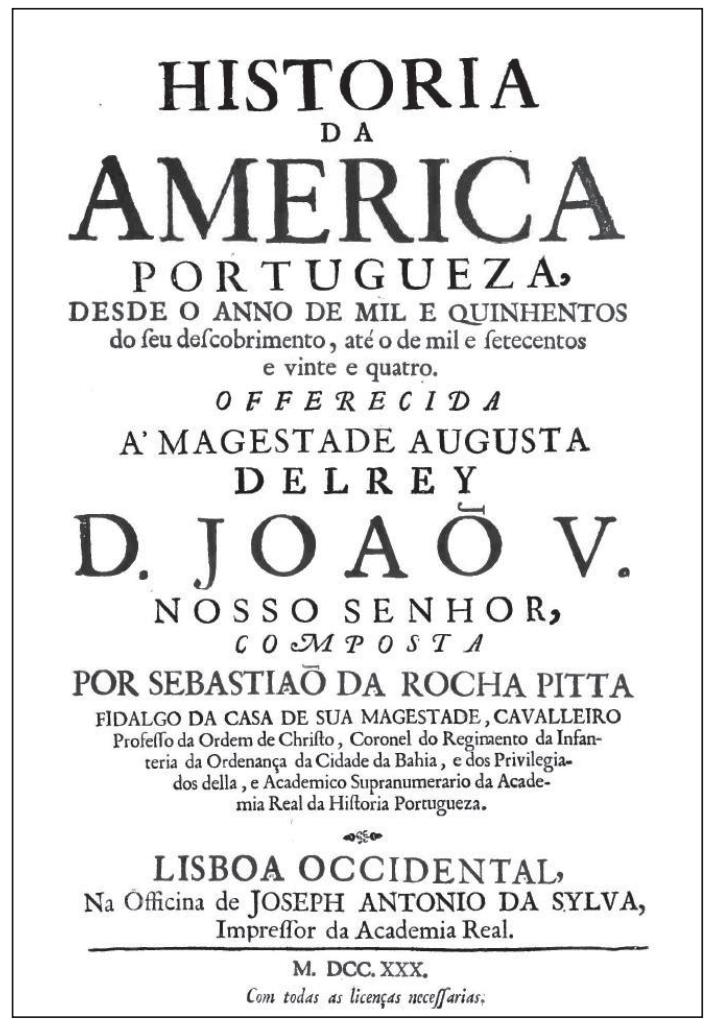

${ }^{117}$ Idem, Dedicatória. 